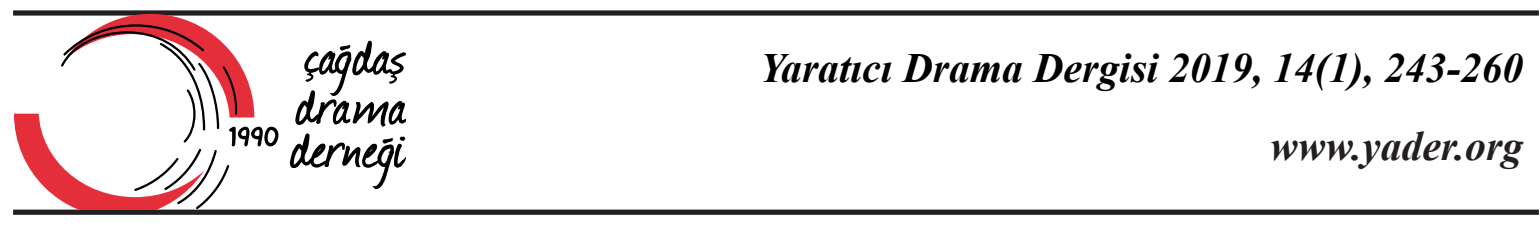

\title{
Teaching Adolescents Civil Law: Process Drama as a Tool for Achieving Legal Literacy
}

\author{
Antigone Laskarides ${ }^{1}$
}

\author{
Alkistis Kontoyianni ${ }^{2}$ \\ Asterios Tsiaras $^{3}$ \\ Christina Zoniou ${ }^{4}$
}

\begin{tabular}{|c|c|}
\hline Article Info & Abstract \\
\hline DOI: $10.21612 /$ yader.2019.014 & $\begin{array}{l}\text { Drama in Education is an experiential way of learning that can be applied in a } \\
\text { variety of ways in many learning fields. This article presents an action research that }\end{array}$ \\
\hline Article His & uses Process Drama as an alternative way of teaching Civil Law class to 16 year \\
\hline Received & old adolescents of the Vocational School of Kranidhi, Greece. Clarifying complex \\
\hline 02.07 .2019 & $\begin{array}{l}\text { legal meanings through Drama is used as a key to Legal Literacy. A pre-test, post-test } \\
\text { design with a control group has been used for the evaluation of the method. In total } 30\end{array}$ \\
\hline Keywords & students of two vocational schools took part. For the experimental group, 24 teaching \\
\hline Drama in education & hours of regular lessons were replaced with teaching using Drama in Education. For \\
\hline Process drama & the evaluation of this intervention, a valid and reliable tool was developed. In addition, \\
\hline Legal literacy & $\begin{array}{l}\text { data were also collected from interviews, participant observations and critical friend } \\
\text { observations. Results support the claim that Drama in Education leads to better }\end{array}$ \\
\hline Civil law & understanding of complex Civil Law meanings and contributes to the proposition of \\
\hline Experimental learning & Drama as an alternative way of teaching in secondary school. \\
\hline Adolescents & \\
\hline \multicolumn{2}{|l|}{ Article Type } \\
\hline Research paper & \\
\hline
\end{tabular}

1 Teacher, 1st Vocational School of Kranidi, Greece. E-mail: antigonelaskarides@gmail.com Orcid ID: https://orcid.org/0000-0002-3284-5281

2 Professor, Department of Theatre Studies, Faculty of Fine Arts, University of the Peloponnese, Greece. E-mail: alkistiseros@gmail. com. Orcid ID: https://orcid.org/0000-0003-4342-7592

3 Associate Professor, Department of Theatre Studies, Faculty of Fine Arts, University of the Peloponnese, Greece. E-mail: tsiast@hotmail.com. Orcid ID: https://orcid.org/0000-0001-6169-6433

4 Special Teaching Staff, Department of Theatre Studies, Faculty of Fine Arts, University of the Peloponnese, Greece. E-mail: czoniou@hotmail.com 


\section{Gençlere Medeni Kanunu Öğretmek: Hukuk Okuryazarlığı Eğitiminde Süreçsel Dramanın Bir Araç Olarak Kullanımı}

\begin{tabular}{|c|c|}
\hline \multirow{2}{*}{$\begin{array}{l}\text { Makale Bilgisi } \\
\text { DOI: } 10.21612 / \text { yader.2019.014 }\end{array}$} & \multirow{3}{*}{$\begin{array}{l}\text { Öz } \\
\text { Ĕ̆itimde dramanın kullanılması öğrenmenin birçok şekline uygulanabilecek } \\
\text { deneysel bir ögrenme yoludur. Bu makale, Yunanistan'da bulunan Kranidhi Meslek } \\
\text { Okulu'nda ĕgitim gören } 16 \text { yaşındaki gençlere Medeni Kanunu süreçsel drama }\end{array}$} \\
\hline & \\
\hline Makale Geçmişi & \\
\hline Geliş tarihi & kullanarak alternatif bir şekilde ögretmeyi kapsayan bir eylem araştırmasını içerir. \\
\hline 02.07.2019 & Karmaşık hukuk anlamlarının drama ile açıklanması hukuk okuryazarlığına giden \\
\hline & $\begin{array}{l}\text { yolda çok önemlidir. Yöntemin değerlendirilmesi için kontrol grubunda ön test- son } \\
\text { test kullanılmıştır. Kontrol grubunda iki meslek okulundan toplamda } 30 \text { öğrenci }\end{array}$ \\
\hline Eğitimde drama & bulunmaktadır. Deney grubunda ise 24 saatlik normal dersler eğitimde drama yöntemi \\
\hline Süreçsel drama & ile işlenmiştir. Ayrıca, veriler görüşme, katılımcı gözlem ve akran gözlem metotları \\
\hline Hukuk okuryazarlı̆̆ & ile toplanmıştır. Sonuçlar, eğitimde drama yönteminin karmaşık Medeni Hukuk \\
\hline Medeni Kanun & terimlerinin anlaşılmasını kolaylaştırdığı savını destekler ve dramanın lise ĕgitiminde \\
\hline Deneysel öğrenme & alternatif bir yöntem olarak kullanılması önerme \\
\hline Gençler & \\
\hline Makale Türü & \\
\hline Araştırma Makalesi & \\
\hline
\end{tabular}




\section{Introduction}

Law can be defined as a system that regulates behavior aiming to achieve social peace and coexistence. Even if people familiarize with rules from the very beginning of our lives, legal system can be so complex that directly determines as "privileged" those who are well aware of its mechanisms, or those who can afford regular access to legal advice and services.

Definition of "Literacy" in general, stands between fundamental human rights, even as a tool for better health treatment, income and fully participation of the person in community and wider society (UNESCO, 2017, p. 14-15). Legal literacy though, is defined as:

"a more complex concept that includes the ability to navigate a legal process with understanding, recognize a legal right or responsibility and recognize when problems or conflicts are of a legal nature" (UNESCO, 2017, p. 15).

However it is clear that understanding fundamental principles of the legal system can be considered as a very basic knowledge, to be introduced yet from school years, it seems mainly to be infused into various standard courses of the curriculum (Pereira, 1988: 4) in most countries. It is though important to clarify that this article refers both in law and educational system as it is established in Greece.

Civil Law as a fundamental branch of Private Law deals almost with all acts of individuals (OECD, 2012, p.12), and also with acts of the state and its bodies in case of acting as individuals. It was the first law branch developed in modern Greece, and serves as a primary source of law, as it is consisted of codified core principles. Civil Law is a social construct highly connected with ethics and etiquette that aims to social peace and coexistence (Varka-Adami, \&Karanasios, 2016, p.15).

"General principles" is the first book of the Greek Civil Code. Legal terms contained in this book are considered the foundation of Law in Greece (Georgiades, 2010:1). Meanings like "Distinction between Law and Ethics", "Grammatical or Logical Interpretation of Law", "Definition of Rights (claim and abuse)", "Subject to Legal Action (natural or legal person)" and "Validity of a legal Act" clarified in "General Principles" are used or combined to form most of the rules of law (Georgiades, 2010, p.1). Therefore the degree of their perception can be used as a legal literacy "barometer".

Though above terms can sound complex, people who aren't aware of the way the legal system works can be alienated and in danger of committing infringements. Most of all they may have limited access to justice. (Zariski, 2011, p.19).

This article emphasizes the need of starting legal education even from high school, where sensitivities and major interests are formed (Zanouzani Azad, 2012, p.19).

\section{Legal Literacy in the Greek Curriculum}

Speaking of the general education Greek curriculum, some of the legal meanings are infused in the course of "Civil Education". It is a class of two hours per week at the second grade of senior high school, containing legal meanings in two out of ten chapters of the schoolbook (Law 4186, Official Government Gazette 193/IssueA'/17-9-2013).

On the other hand, in Vocational schools, law meanings are included in the curriculum of the second grade sector "Management and Economy", where, under the title "Elements of Law", is 
taught a law-targeted class of four hours per week (Law 4386/ Official Government Gazette 1567/ IssueB'/2-6-2016).

In Vocational schools, students of the Management and Economy sector are prepared for a "fast entry" in practical application of rules of law. Therefore the teacher has the opportunity to present the General Principles of Civil Law, using many examples of everyday life and simulating the UNESCO definition for Legal literacy (UNESCO, 2017, p. 15).

\section{Drama in Education as a Tool for Experiential Learning}

Presence of Drama in Education exceeds its artistic dimension. It can be a field where a variety of methodological approaches, tools and techniques can be used by the teacher as learning mediums (Avdi, \& Chatzigeorgiou, 2007, p. 20).

Through the natural process where make-believe play serves learning, Drama in Education uses body movement, rhythm, speech, sound, role-play within the educational environment, giving participants new perspectives through familiar techniques, making understandable the complex world we live (Kosti, 2016, p.78).

The contribution of Drama in experiential learning consists in a complex procedure of both theory and application, action and reflection (Alkistis, 2008, p. 165). Participants live the experience building an imaginary world, still keeping views of the real (Avdi \& Chatzigeorgiou, 2007, p.42). Theatrical elements like: role playing, dramatic tense, focus, place, time, language, movement, atmosphere, symbol and dramatic meaning are claimed to create this imaginary world (O'Toole, 1992, p.13-46).

Process drama is almost identified as Drama in Education. However Process Drama arises in the 80 's as an attempt to define a more structured dramatic form from less complex theatrical techniques used in education(Taylor, \&Warner, 2006, p.3). It seems more focused in creating a series of episodes (Fransen, 2003, p.8) that are not necessarily linear (Taylor, \&Warner, 2006, p.3). Mostly is a way of focusing in different point of views of the objective. The teacher, who is often participating in Drama, is leading the point of view.

Cecily O' Neill, who was inspired by Dorothy's Heathcote famous work, gives the definition in her book under the title "Drama Worlds, A Framework for Process Drama” (O’Neil, 1995, p.xiii):

"Process drama is a complex dramatic encounter. Like other theatre events, it evokes an immediate dramatic world bounded in space and time, a world that depends on the consensus of all those present for its existence. Process drama proceeds without a script, its outcome is unpredictable, it lacks a separate audience and the experience is impossible to replicate exactly".

\section{Process Drama for Conducting Action Research}

According to Reason \& Bradbury (Reason \& Bradbury, 2008, p.1):

"Action research is a family of practices of living inquiry, that aims, in a great variety of ways, to link practice and ideas in the service of human flourishing. It is not so much a methodology as an orientation to inquiry that seeks to create participative communities of inquiry in which quality of engagement, curiosity and question posing are brought to bear on significant practical issues" 
Process Drama, focusing in different point of views of the objective, seems to empower action research processes (Tofteng et al., 2011) giving the researcher the opportunity both to intervene and to conduct his study. It seems that, in a way, Process Drama interventions for research reasons concur with action research while in both cases learning is produced by the participants (Athanasiou, 2007, p.330).

\section{Literature Review}

Literature on the teaching of law mainly approaches students of higher education. While educational methods used in Law Schools are highly related to theatrical techniques (Friedland, 1996 ,p.27), the main target is familiarization with the role of the lawyer and legal speech (Stuckey, 2007, p.121), and much less with experiential understanding of parts involved. Even less they intend to clarify the logical reasoning of the legislator.

Under this angle, many experiential workshops with role-playing are presented in Roy Stuckey's (Stuckey, 2007) book, "Best Practices for Legal Education".

As more specified research for using Drama in legal education is the one of Scully-Hill et al. (Scully-Hill et al., 2010) "Beyond Role Playing: Using Drama in Legal Education". It is both an empirical and bibliographical research in Hong Kong University that reveals the benefits of theatrical acts of law students (that took place for non-educational purpose), in understanding all points of view of the legal system.

For teenagers, law teaching methods are pretty poor, while a research concerning the use of Drama for teaching adolescents the law couldn't be traced.

Research tools for data collection upon the legal literacy of adolescents are developed in two levels: In countries with great illiteracy rate research is focused on the knowledge of governmental or religious power limits while in western countries it is focused on the knowledge of rights upon a certain subject (i.e. bullying).

Among above research using questionnaires as research tools, the most relevant to general law knowledge of adolescents is the one that took place in England and Wales on behalf of the Legal Services Board and the Law Society in 2015. The research concerns mainly adults, but a part of it is designed for teenagers (IpsosMORI, 2016, p. 129) aiming to find the source of their legal information and consulting. Again here, data collection for understanding fundamental legal meanings, is not present.

All above support the development of a new research tool adjusted to study the level of Legal Literacy of teenagers.

\section{Research Limitations}

The most obvious limitation of this research is the small sample size. Number of participants was finalized after pre-test. In addition one participant never completed the post-test questionnaire. This fact prevents a clear generalized statement about the impact of the teaching method.

Occasionally, absence of students was substituted by reflective discussion in the next intervention. This, of course, cannot prevent learning gaps. 
One of the interventions (the eleventh) was not properly completed. School finished one hour earlier due to a bus change of schedule and the intervention was limited in narration and reflective discussion.

Critical friend could not be physically present during the interventions as planned. This led in video-taping the lessons with the consent of participants. It is possible that the presence of a camera in the room affected the freedom of expressions of the participants. Additionally, the perception of the drama atmosphere is difficult to be recorded on camera.

On behalf of the teacher, the use of Drama proved to be demanding and required persistence. All lessons plans were designed from scratch. Process Drama requires fantasy, alertness and adjustability to the team of participants. Sometimes preparing a lesson needed many hours of preparations, while teaching time proved to be energy consuming.

\section{Research Method}

Objective of the research was to teach Civil Law using process drama in a Greek vocational school and compare results linked to Legal literacy with the traditional way of lecture-based learning.

Fundamental legal meanings contained in General Principles of Civil Law were selected on the basis of their relevance with the school curriculum goals (Official Government Gazette 1561/ issueB'/17-8-2007), for the course "Law Elements". Selected meanings are: "Distinction between Law and Ethics", "Grammatical or Logical Interpretation of Law", "Definition of Rights (claim and abuse)", "Subject to Legal Action (natural or legal person)" and "Validity of a legal Act".

Five research questions were focusing on whether each one of those terms were better perceived and understood by adolescents, when teached with Drama techniques.

Twelve two-hour classes of traditional lecture-based teaching were replaced with twelve workshops-interventions, using Drama in Education. The effectiveness of the intervention was evaluated with pre-test, post-test and control group.

Two groups of students of the Economy and Management sector of Vocational schools were selected using convenience sampling. Both groups were pre-tested, while first group (experimental) was affected by the independent variable (Drama in Education). Level of results was measured after the intervention for both groups in order to study possible differentiation between two groups. Experimental group was consisted of 15 students of Kranidhi Vocational school (11 girls and 4 boys), while control group was consisted of 15 students of Nafplion Vocational school (3 girls and 12 boys).

\section{Data Collection Tool Development}

Effectiveness of the intervention was measured for both groups using a questionnaire of quantitative research, developed with closed questions of Lickert type (Anderson et al., 1983: 253) focused on the level of understanding law meanings.

Items were divided into five factors (five research questions). The questionnaire was evaluated for item clarity and completion time (by a small pilot survey), content validity (content validity ratio $>0,99$ ) by 3 law professionals and 3 teachers (Berk, 1990: 659) and for its reliability (Cronbach's alpha $>0,7$ for each factor) by a second pilot survey. Data were processed by the SPSS 
(Statistical Package for Social Sciences) software. Final questionnaire was formed to 31 questions and completion time 20-25 minutes and value of Cronbach's alpha 0,741

\section{Data Collection Process}

Both the experimental and the control group were pre-tested before and post-tested after the interventions, using the research tool, in order to study possible quantitative differentiation between two groups.

After pre-test results, standard deviation was calculated $\mathrm{s}=11,7$ for the experimental group and $\mathrm{s}=18,17$ for the control group. Confidence interval was selected to be $95 \%$.

At the same time qualitative research tools were also used in order to confirm results of the quantitative data: interviews of the students, participant observation diary and the presence of a critical friend.

\section{Short Description of the Interventions}

Twelve lesson plans were developed emphasizing experiential learning through Drama in Education, mainly through Process Drama. A classroom that was out of use was emptied, well cleaned, wall decorated and carpeted. Students were welcomed in an empty room with discrete music and air-freshener scent. Each two-hour class was replacing two hours of traditional lecturebased teaching with Process Drama for the experimental group, while the same teaching time for the control group was taking place traditionally in the classroom.

Interventions were divided in five main topics related to the five legal meanings forming the research questions. Sub-topics were also formed in most cases, consuming more than one intervention. Each two-hour class was devoted to one sub-topic. Topics, sub-topics and interventions are shortly described below.

All interventions were starting with a specially designed warm-up game, relevant to the topic. Neelands and Goode techniques (Neelands, \&Goode, 2015) either variants or the same, were used for building a story in episodes. Episodes were connected with narration. Each story was a well understood practical example of the topic studied, sometimes providing a moral dilemma, while many were based on true stories. Participants were mostly embodying collective roles, enlightening different points of view to the story, while dramatic action was conducted by the teacher. The pattern beginning - climax - end was developed for each of the stories. After the end of the story, a reflective discussion was necessary to summarize the experience (Alkistis, 2008: 165).

\section{Distinction Between Law and Ethics}

Even if ethics affects rules of law, there is no absolute identification of law and ethics (VarkaAdami \& Karanasios, 2016:16). It is often acceptable not to accord rules of law and show loose morality (i.e. avoid taxation), while immoral acts don't seem to violate law (i.e. indifference for our neighbor). And in first case penalties are suggested, while in the second case the result may be only social disapproval or sense of guilt. This basic difference is crucial for setting the operational limits of the legal system. (Varka-Adami \& Karanasios, 2016: 16). 


\section{“I have no scepter, but I have a pen”}

A Process Drama was planned upon the true story of the 17 year old first king of newer Greece, Otto. The young king had to legislate from scratch upon citizen's requests (teacher-in-role) with the help of his trusted advisors (collective role). This concept was leading the participants-in role of advisors both to legislate and to organize legal rules.

The main goal was to clarify that legal system is a man-made construct highly connected with ethics and etiquette, but not absolutely identical to them.

\section{Grammatical or Logical Interpretation of Law}

Sometimes law texts are composed in a way that creates discussions concerning the meaning and the scope of application (Varka-Adami \& Karanasios, 2016: 24). Interpreting the meaning of a legal text is a matter of scientific study and can lead to word correction of the text. Therefore the importance of understanding the difference between "letter and spirit of law" and the fact that each legal text raises a logical reasoning of the legislator, may work both as a tool of legislation and as a tool of claiming justice in courts.

\section{"Standing on expectations"}

The concept of a strange family living together in a big house, under democratic rules was the main idea of the Process Drama. Father had to leave for a few days, leaving written instructions for everyone in the family (collective roles of wife, children, brother, grandparents). In some occasions, it was useless to follow those rules (i.e. wash the car under heavy rain). Participants had to decide and justify why they would follow or not written instructions.

Drama was emphasizing the clear division between the letter and the spirit of a rule. During the reflective discussion the story was brought to legal texts and their interpretation grammatically or logically.

\section{Definition of Rights (claim and abuse)}

Meaning of right is not clearly defined in Civil Law. However it is admitted as a power of individuals to satisfy and protect their interests (Varka-Adami \& Karanasios, 2016, p.29). On the other hand, it is well defined and clearly limited the meaning of abuse of rights. Article 281 of the Greek Civil Code provides that:

'the exercise of a right is prohibited where it manifestly exceeds the bounds of good faith, morality or the economic or social purpose of that right".

All above are delicate legal terms. Good faith is connected with honesty and fairness required from people that live in the same society. Morality reflects the way of thinking of a human community. Economic or social purpose of the right supports the satisfaction of the interest of a community that should prevail over the satisfaction of interest of an individual.

Even if it seems difficult for non experts to perceive, these terms are present in the routine of everyday transactions and necessary to know in order to equally participate in citizenship. In addition to all that, claiming of rights is a matter of legal processes (and not physical force). Well defined limits of our rights makes also clear when it is admitted (or not admitted) to take law in our hands (Article $282 \& 283$ of the Greek Civil Code). 


\section{"Small fisherman - big fisherman"}

As an example to the economic or social purpose of the rights it was invented the story of a fishermen village. The word was spread thata fisherman spent his lifetime savings to buy a big fishing boat with trawl nets. Trawl nets give great profit but can be destructive to the sea environment. Participants in role of villagers had to decide whether their colleague (teacher in role) was exceeding the bound of his right to use his savings the way he wanted.

\section{"Is it my right? I don't think so!"}

The concept of sexual harassment in the workplace was a spicy example concerning morality while exercising a right. It is a right of an employer to choose his employee, but can it be his right to fire a woman because she rejected a date proposal? The employee claimed back her job and participants in role of lawyers had to decide whether they wanted to defend the employer (teacher in role, using a puppet).

\section{“Are we friends or not?"}

The well known case of the popular American series "Friends" was used as a context for clarifying the meanings of good faith. Participants in role of actors signed to participate in a series for the local tv market and got paid. The scenario was smart and the series became a world success. The producer made profit beyond expectations. Actors claimed to re-arrange their payment, but the producer kept his rights upon the initial contract. Participants had to make arguments for both sides and decide whether the right of the producer to keep the initial contract was exceeding the bound of good faith.

\section{"Dynamic beauty"}

The admission (or not admission) of taking the law into our hands was attempted to be clarified with the invented story of a mysterious old woman who recently died. Participants in role of children of the neighborhood discovered in her garden's house a box with souvenirs of her life. The old woman proved to be an ex-miss Greece with a hot-tempered personality. Pieces of newspaper revealed that four times in her life took the law into her hands. Three of them she was punished and one she was awarded. Completing a life-puzzle the participants should find out the consequences of her initiative.

\section{Subject to Legal Action (natural or legal person)}

Whether we speak about natural or legal persons it is important to know when ability for legal action begins and when it ends. However in legal persons this is defined in a written statute, for natural person it is not as clear as it seems. Questions like when an individual begins to have legal rights, or what happens legally when a person is missing, are of everyone's concern. And even if it is not possible to know all relative legislation, it is important to understand the logical reasoning of the legislator.

\section{"Love for Maria"}

The beginning of existence for a natural person in law terms is a complicated mater that should exceed any philosophical questions or religious beliefs. According to the Article 36 of the Greek Civil Code, the existence of a natural person begins with conception under the condition that is born alive. If not, it never existed. 
Process Drama used an invented story, inspired by the story of the famous soprano Maria Callas. Maria is pregnant from a famous married millionaire. Even this is a big scandal and a headache for the millionaire and his wife, the millionaire is proved to be very sick. And a few months later he dies, before the birth of his child. Can Maria claim (on behalf of her baby) a part in his will? Maria's friends (collective role of participants) have to counsel her in every step of the way.

\section{"Andrew is disappeared"}

The end of the existence for a missing person is a matter of court decision and is the only way to deal with practical matters like heritage or end of marriage. The invented story of the Process Drama was inspired by a true story in the local community. Andrew, a young seaman recently married, was travelling from Mexico to Europe. On board he was disappeared and never found. His family had to deal both with mourning and with practical issues. Participants in collective family roles have to deal with the decision of legally ending Andrew's existence.

\section{Validity of a Legal Act}

Our social life contains everyday legal acts like buying and selling, rentals, loans, contracts etc. Their validity protects our interests. Civil Code defines four conditions (beside our will) in order to have a valid legal act. One is the capacity of a person for legal actions (i.e. underage persons have limited capacity for legal actions and gradually from birth till adulthood this capacity extends). (Varka-Adami \& Karanasios, 2016: 60). Next is the accordance between declaration and will (i.e. it is not valid a legal act if one part did not understand its meanings or was fooled or even was joking). Third is the adherence to a certain form which is not the same for all legal acts. In some cases an oral agreement is enough, while in other cases a notarial deed is needed (Varka-Adami \& Karanasios, 2016: 63). Finally a legal act should not contain immoral or illegal content (VarkaAdami \& Karanasios, 2016: 64) (i.e. no deal is valid if binds human freedom, like change of religious beliefs for money).

\section{“Indecent proposal”}

For clarifying the immoral content of a legal act, the context or the Process Drama was presenting a story very similar to the famous movie "indecent proposal". Diana is a married young woman. An old friend, who is obsessed with her since childhood, offers a great amount of money in order to spend a night with her. Participants in role of family friends cannot affect the couple's decision. But they can criticize afterwards the validity of the contract, when the old friend denies paying the amount agreed.

\section{"Popi's signature"}

The invented story of an old woman named Popi, was aiming to clarify when a person is capable for legal actions, and what happens if he is not. Popi dies and her children discover that she left her house to her housekeeper grateful for her care. A sly lawyer (teacher in role) suggests to her children to claim in court that Popi had lost her mind and that her will is not valid. An imaginary trial is set with participants in different roles: friends, family, housekeeper, lawyers and court.

\section{"The contract template that was bought at a kiosk"}

The adherence to a certain form is one of the conditions in order to have a valid legal act. Process Drama was dealing with a young man who recently left his parent's house and rent a small 
apartment, making a simple contract with the owner. Taking for granted that this is the only way to deal, made again a simple contract, this time to transfer real estate. Participants in role of the young man had to deal with the consequences and think of the reasons that different forms are needed in different legal acts.

\section{“Meteorite from Santorini"}

Theofilos, a collector of rare objects, was the main character of the Process Drama. He is persuaded that the small statue he bought in the market was made of meteorite stone. After an expert (teacher in role) examined the object, it proved to be made of volcanic lava. Theofilos asked for his money back, proving his claim with the description on the invoice: "Statue made of meteorite stone". Participants in roles of the shop-owner, of Theofilos and of his consulting friend had to deal with a case of discordance between declaration and will.

\section{Results}

After the completion of the interventions, the participants of the experimental and the control group completed the post-test questionnaire. Personal interviews of the participants and the critical friend took place within the following month. SPSS 20.0 (StatisticalPackageforSocialSciences) software was used to analyze quantitative data. Student's T-test was used to compare values of the means from the two groups and examine if their difference is statistically significant. Qualitative data were organized in groups in accordance to research questions.

\section{Reliability of Research Tool}

Questionnaire was checked again for reliability in pre and post-test to both groups with Cronbah's alpha value $>0,7$ for each factorand in total (Table 1).

\section{Table 1}

\begin{tabular}{|l|l|l|}
\hline Group & Pre-test & Post-test \\
\hline Experimental & 0,791 & 0,772 \\
\hline Control & 0,818 & 0,712 \\
\hline
\end{tabular}

\section{Normality Test}

Both groups (sample $\mathrm{n}<50$ ) were tested for normality using the Shapiro-Wilk test (Singh, 2007:100) and was found $>5 \%$ (since confidence level was defined $95 \%, 5 \%$ is the limit for determining that null hypothesis $\mathrm{H}_{0}$ is reasonable), indicating that our sample is normally distributed.

\section{Null Hypothesis Definition}

Null hypothesis $\left(\mathrm{H}_{0}\right)$ is that there is no significant difference in the effectiveness of teaching adolescents using Drama in Education compared totraditional teaching in understanding complex Civil Law meanings.

Alternative Hypothesis $\left(\mathrm{H}_{1}\right)$ is that there is significant difference in the effectiveness of teaching adolescents using Drama in Education compared to traditional teaching, in understanding complex Civil Law meanings. Level of significance is defined $5 \%$. 


\section{Compare Means and Standard Deviation (pre-test)}

T-test was used in order to compare means between experimental and control group and compute the standard deviation, before the interventions. Mean value was 85,38 for the experimental group and 79,21 for the control group. Levene's test was used to check the equality of variances, a condition necessary for applying parametric tests (Singh, 2007:102). Value of $p=0,135(p>0,05)$ indicates equality of variances for the two groups.

Running t-test estimatesp $>0,05(\mathrm{p}=0,300), \mathrm{t}=1,059, \mathrm{df}=25$. These values indicate that before interventions, differences between two groups are not statistically significant in terms of legal literacy measured by our questionnaire.

Standard deviation for both groups was also estimated $\mathrm{s}=10,90$ for the experimental group and $s=18,18$ for the control group.

\section{Compare Means and Standard Deviation (post-test)}

After interventions mean value was measured 105,69 for the experimental group and 86,71 for the control group. Levene's test indicates again equality of variances for the two groups $(p=0,916)$.

Running t-testestimatesp $<1 \%$. Even if preliminary, this is an indication of statistically significant difference between means.

Standard deviation was estimated $\mathrm{s}=10,27$ for the experimental group and $\mathrm{s}=11,17$ for the control group.

\section{Running t-test- Estimation of the p-value.}

Independent t-test determines whether there is a statistically significant difference between two samples. Dependent variable (legal literacy) is common for the two groups with no overlapping between participants. In our case, we are interested in improvement and not just difference of the experimental group. Therefore t-test is conducted one-tailed, towards positive direction (Emvalotis, Katsis, \& Sideridis, 2006:60).

SPSS software cannot run one-tail test. This is why $\mathrm{p}$ is calculated as half of the p-value estimated by two-tailed test (Emvalotis, Katsis, \& Sideridis, 2006:60).

Results indicate increased means for the experimental group in all factors, except "subject to legal action" where improvement is almost the same for both groups. P-value varies per factor. Data of all factors, summarized under the mean of "Legal literacy" show a statistically significant improvement for experimental group from pre to post-test (Table 5), as $\mathrm{p}$-value is estimated $\mathrm{p}=0,007$ $(\mathrm{p}=0,013$ for two tailed test). Means of both groups during pre-test may indicate quite same level of knowledge, while post-test show a positive differentiation for the experimental group (Diagram 1).

Table 5. Legal literacy T-Test

\begin{tabular}{llllll}
\hline Group Statistics & & & & & \\
\hline & GROUP & $\mathrm{N}$ & Mean & Std. Deviation & Std. Error Mean \\
\hline Difference & Kranidhi & 13 & 20,3077 & 10,01153 & 2,77670 \\
\cline { 2 - 6 } & Nafplio & 14 & 7,5000 & 14,19507 & 3,79379 \\
\hline
\end{tabular}




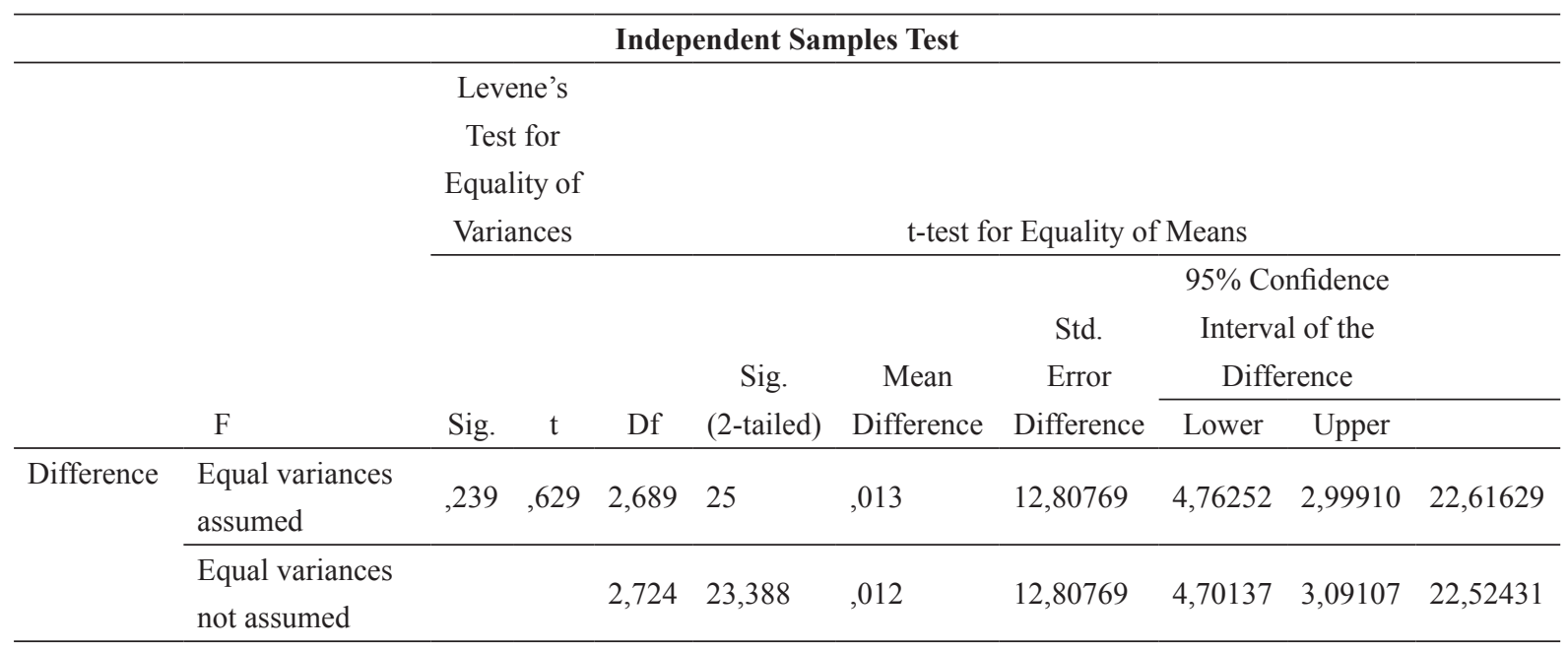

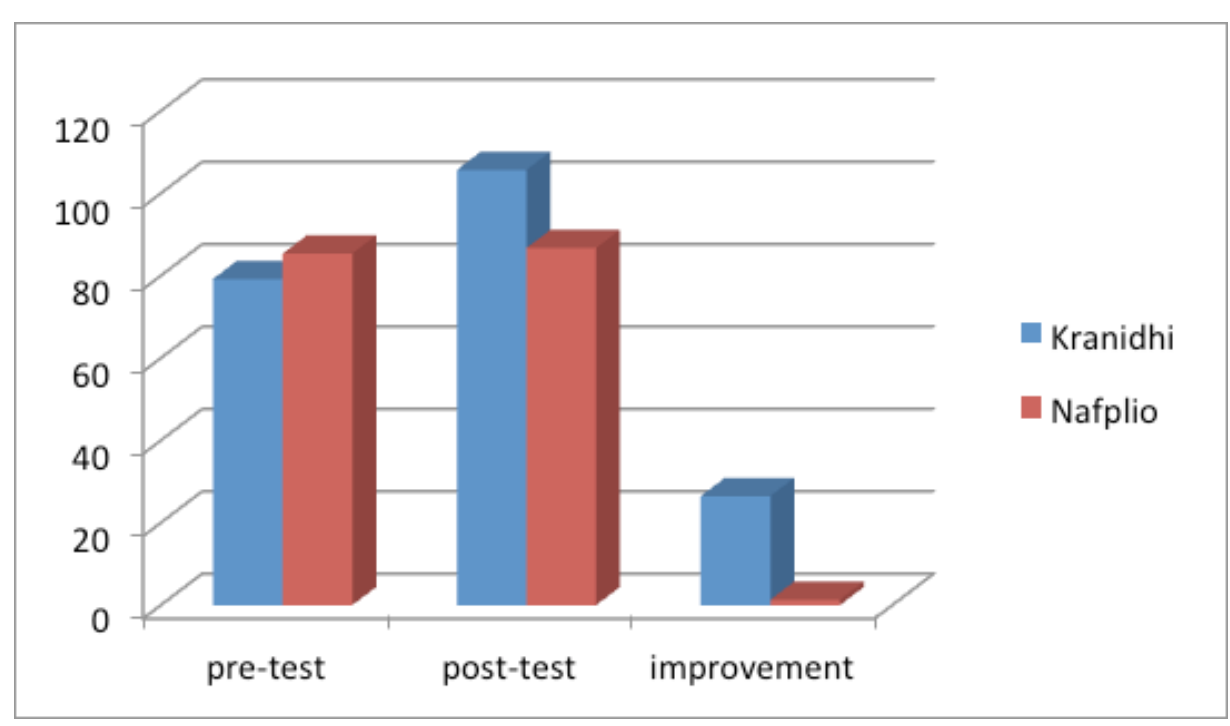

Diagram 1. Legal Literacy (means in total)

\section{Qualitative data}

During, but mostly after interventions, the teacher kept an observation diary with general and special notes both for discussion and for improvement of the following lesson plans. The physical presence of a critical friend was not achieved. However, all interventions were videotaped with the consent of participants and commented-evaluated by an experienced colleague of the same school (Swaffield \& MacBeath 2005: 250). Interviews of the participants took place two weeks after the last intervention.

Qualitative data were organized into three main groups: student's response in legal literacy, learning outcome, effect of the teaching method in other fields of learning (like team building or finding new skills) that can also count for the perception of legal literacy.

\section{Response in Legal Literacy}

Positive response is necessary for adolescents to accept familiarizing with difficult legal terms. The new teaching method was clearly noted as a "good change" for the $100 \%$ of the participants 
while 70\% experienced freedom of expression. Justification for "good change" came with more qualitative data, while a great percentage connected this belief with experiencing a sense of freedom. It seemed that even the fact that the environment was different than typical classroom was perceived positively by the participants. Interviews showed that:

"It was not a classroom with desks. We were more free"

"We could talk to each other and play without being suspended"

"It was not a regular lesson. We were playing games, we had a team spirit. The best moments in classroom".

"I liked that we were playing roles"

"It was not a boring lesson"

"Time was passing pleasantly and creatively".

"It was better because we were working all together. I was hoping not to end".

When a student was asked to mention disadvantages or problems, he joked:

"Problem is regular class".

Observation diary clearly indicates that both participants and the teacher were gradually familiarized with the new teaching method. Hesitation was quickly reversed to eagerness after the third intervention. The classroom adopted for Drama interventions was called before "the dungeon". At some point the word "dungeon" gained positive meaning as a synonym to the new teaching method. Near the twelfth intervention, students were expressing privileged for having the chance to spend time in the "dungeon". This sense of privilege was often expressed outside the classroom and noted by the teacher.

"Thank God we're going to the dungeon".

"Why don't you take us too in the dungeon? Why only them?"

"Are you crazy? Tomorrow we go to the dungeon. I don't want to miss it!"

It is also admitted that students that showed difficulties in adjustment in regular class, were also difficult to adjust in Drama procedure. Making noise, drawing attention, and unwilling to participate was almost a routine. However they were the most eager to go to the "dungeon" and they showed remarkable improvement in perception.Critical's friend notes confirmed both the gradual adjustment and the difficulties of certain students. Additionally critical friend observed that noise was directed and related to the teaching subject and was not distraction.

\section{Learning}

In all teaching subjects learning is an objective tested with written exams. As far as Legal Literacy is concerned we may say it is more than that. Learning value has to do mostly with understanding the law-logic relation than just remembering rules. Understanding of this logic is crucial for being usable in the future when needed (Zariski, 2011:19).

Interviews justified the results of quantitative analysis in terms of learning results. Students claim to have better understand $(84,62 \%)$ legal meanings, while the majority claims to remember most of what he learned $(92,31 \%)$. 
Some of the answers were:

"It was easier to understand from the examples"

"It was sticking to the mind like a game"

"We were participating in the stories and we could remember afterwards"

"We had to combine theory and action. It was easier because we were living the story and we didn't have to study it".

Better perception was also noted in the observation diary. Discussion between students reveals they were directed towards logical reasoning. One of many such examples noted in the diary, is the following dialogue:

M: "Why is Costa's fault if his neighbor was ill and died out of negligence? Was he responsible for him?"

Teacher: "Could he be responsible in some case?"

L: "If his child was dead, yes he should have been punished. What about now?"

Teacher: "Why he should have been punished then?"

L: "It was his responsibility".

Teacher: "Ok then. Can we compose the text of the law?"

M: "Red (big) penalty in case of death out of negligence of people that we are responsible of."

G: "It's not right. He should have informed the authorities for his neighbor. He should be punished for not informing”.

L: "Yes. But with a yellow (medium) penalty".

M: "I don't agree. He is not responsible for his neighbor. He may not even know he was ill. I vote for no penalty". At the end of the intervention, students edited a paragraph very similar to the reasonable logic of today's legislation:

"In case of death of negligence of a person under our responsibility we get a red penalty. In other case, should be examined if there was a way to help (yellow penalty) and if not we get no penalty"

Qualitative data confirm the statistically significant improvement of the experimental group in quantitative research concerning the level of Legal literacy. Evaluation test for the semester showed a high mean in grades (16/20) while all participants, according to the teacher council, constituted a bonded team. Teacher council and critical friend also noted that this improvement appears only in Civil Law class and not in other teaching subjects.

\section{Effect in Other Fields of Learning}

Qualitative data were also indicating affection in other fieldslike team bonding or finding new skills or even better concentration. A $76,92 \%$ noted that after interventions could work better in team. A 38,46\% discovered new skills and a 23,08\% noted improvement in concentration.

Team working is important in all learning process as a way to concentrate different resources from different participants to a capital disposable to all team members (Barkley, Cross\&Major, 2005: 22). Interviews showed better collaboration between members of the group. 
"Team bonding games were helpful in solving problems"

"I can do better if we work as a team"

"Sometimes it was difficult to decide. Many opinions were heard. At that point I think it was easier to decide".

Negative comments were also focusing in difficulties of collaboration between participants. A $30,77 \%$ seemed to be disturbed from those who denied to participate while a $46,15 \%$ felt bothered from participants that were joking, spoiling drama atmosphere. The bonding achieved seems that led into other objectives too, like team working for funding the annual excursion.

Finding new skills is another field affected by the use of Drama. Even if it is not directly related to Legal Literacy, finding new skills seems to be connected with self confidence (Bunker, 1991: 469). Claim of rights is a necessary component in citizenship. Many legal rules are produced by citizen's claims. Self confidence is a way to activate claiming. To the question whether they found something new about themselves, some students answered:

"I discovered that it was not so awkward to draw attention".

"Now I can stand them easier (my colleagues)".

"I found out I could say my opinion even if I disagree with the others".

"I liked the role playing. I think I would like to play theater".

"Before dungeon, I was ashamed of my voice. Now I like the way I talk".

Finding new skills was also mentioned in the observation diary. Some of the participants became members of the theatrical team that year ( 3 students), some presented a documentary film (4 students), some participated in scenery and puppet construction (7 students).

Self concentration was also noted in some students' interviews. Lack of self concentration needs special learning treatment. Observation diary does not contain this element. However an important note of the critical friend is related. Sometimes action seemed to stop and discussions seemed to skip basic rules of civilized dialogue. Teacher was making remarks to bringing the class back to order. Critical friend noted that most of the noise was expressing passionate defending of the right which is a healthy and desirable reaction.

\section{Discussion}

Small sample size of the research prevents any generalized statement beyond the context of this study. Howeverthe findings in this limited context were clearly positive. What is already reported in existing literature -that the use of Drama can be used by the teacher as a tool for experiential learning (Avdi, \&Chatzigeorgiou, 2007, p. 20) is justified by this research with very good results.

Applying process Drama for the understanding of difficult learning subjects like general principles of Civil Law and for the clarification of its difficult terminology indicates successful results. Compared to the traditional lecture-based teaching, the use of Drama seems significantly more effective in achieving Legal Literacy.

Legal literacy in the present research was identified as a group of five factors: "Distinction between Law and Ethics", "Grammatical or Logical Interpretation of Law", "Definition of Rights (claim and abuse)", "Subject to Legal Action (natural or legal person)" and "Validity of a legal Act". 
Quantitative analysis of data showed a statistically significant improvement for the experimental group in comprehension and perception of the above legal meanings, if compared to the control group that was traditionally taught.

Beyond these results, qualitative data revealed delicate qualities in the learning process. Positive respond of the students to the new teaching method helped the transformation of the juridical language into practical and everyday examples and the better perception of Legal Literacy. Students accepted gradually the new way of teaching and identified it as freedom of expression. In addition, team bonding assisted the learning process where different points of view of each different participant, led to multidimensional study of the subject. This can be considered very important, for this is the point when legislating. Furthermore, self-concentration appeared as another benefit between participants that assisted the learning process.

Finally, during interventions participants had the chance to discover new skills that in a way gave them more confidence. Self confidence is a basic component when claiming rights, therefore is required in matters of Legal literacy.

\section{Conclusion}

This research suggests the introduction of Civil law into general education senior high school, as, beyond any doubt, Legal literacy is an important part of citizen's general education. Difficulties in clarification of legal terms posed this knowledge in third-grade specialized education.

Civil law as a school lesson can be proved complicated due to its theoretical nature and the difficulty of correlating legal terms with practical examples of everyday social life.

The use of Drama in education emphasizes in critical thinking (Alkistis, 2008: 77). By provoking discussions and criticism, Drama enlightens social issues (Sextou, 2007:24). Adolescents of secondary education are the future adult citizens. They will be able to take decisions as equal members of the society only if they are legally literate (UNESCO, 2017: 15). Role playing through Drama gives them the opportunity of interacting and examining dilemmas under different points of view. This is exactly the way the legislative system should work. Drama as a way of understanding reasonable logic of the legislative system copies the way this system works, therefore can be proved as an effective tool for Legal literacy. 


\section{References}

\section{English}

Anderson, A., Basilevsky, A., Hum, D. (1983). Scaling techniques. In P. Rossi, J. Wright, \& An. Anderson (Ed.) Handbook of Survey Research: Quantitive Studies in Social Relations (pp.246-281). Massachussets: University of Massachusetts Academic Press.

Barkley, E., Cross, P., Major, C.H. (2005).Collaborative learning techniques: a handbook for college faculty. San Francisco: Jossey-Bass.

Berk, R. A. (1990).Importance of expert judgment in content-related validity evidence.Western Journal of Nursing Research, 12(5), 659-671.

Bunker, L. (1991). The Role of play and motor skill development in building children's self-confidence and self-esteem. The Elementary School Journal, 9(5), 467-471.

Cronbach, L. J. (1951). Coefficient alpha and the internal structure of tests. Psychometrika, 16(3), 297-334.

Fransen, W.J., (2003). Process drama and creative problem solving: an Integrated Approach. Dissertation in Fine Arts, Texas Tech University Library.

Friedland, S. (1996). How we teach: A survey of teaching techniques in American law schools. Seattle University Law Review, 20(1), 1-44.

Gervais, M. (2006). Exploring moral values with young adolescents through process drama. International Journal of Education \& the Arts, 7(2), 1-34.

Ipsos MORI (2016). Online survey of individuals' handling of legal issues in England and Wales 2015. The Law Society \& Legal Services Board, UK. Recovered by : http://www.lawsociety.org.uk/support-services/ research-trends/largest-ever-legal-needs-survey-in-england-and-wales. Date of visit: 19/4/2017.

Landy, R. (1982).Handbook of educational drama and theatre. Connecticut: Greenwood Press.

Neelands, J., \& Goode, T. (2015).Structuring drama work, 3d Edition. Cambridge: Cambridge University Press.

OECD (2012).Greece: review of the central administration (Greek Version): OECD Public Governance Reviews. OECD Publishing.

O'Neill, C. (1995). Drama worlds, a framework for process drama. Portsmouth: Heineman.

O'Toole, J. (1992). The process of drama: Negotiating Art and Meaning. London: Routledge.

Pereira, C. (1988). Law related education in elementary and secondary school, Eric Digest, ED296948 198806-00, https://files.eric.ed.gov/fulltext/ED296948.pdf

Reason, P., \& Bradbury, H. (Eds.). (2008). Handbook of action research: participative inquiry and practice. London: Sage Publications.

Scully-Hill, A., Lam, P., \& Yu, H., (2010). Beyond Role Playing: Using Drama in Legal Education. Journal of Legal Education, 60 (1), 147-157.

Singh, K. (2007). Quantitative social research methods. New Delhi: Sage Publications

Stuckey, R. T. (2007). Best practices for legal education: a vision and a road map. South Carolina: Clinical Legal Education Association.

Swaffield, S., \&MacBeath, J. (2005).School self-evaluation and the role of a critical friend. Cambridge Journal of Education, 35(2), 239-252.

Taylor, P., \& Warner, C. D. (2006) Structure and spontaneity-the process drama of Cecily O'Neill. London: Institute of Education Press.

Tofteng, D. \& Husted, M. (2011). Theatre and action research: How drama can empower action research processes in the field of unemployment. , 9(1) 27-41.

U.N.E.S.C.O., (ed) (2017): Reading the past, writing the future: fifty years of promoting lliteracy, France. Recovered: http://unesdoc.unesco.org/images/0024/002475/247563e.pdf (Data base: UNESDOC of UNESCO). Date of visit: 17/4/2017. 
Zanouzani Azad, L. (2012). Fairness through legal literacy: a case for active involvment. Master's Thesis, University of Waterloo, Ontario, Canada.

Zariski, A. (2011). Legal literacy: An introduction to legal studies. Edmonton: AthabascaUniversityPress.

\section{Greek}

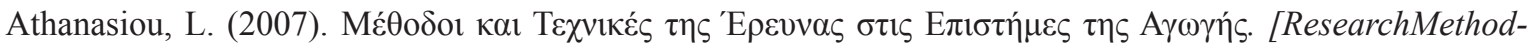

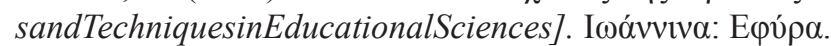

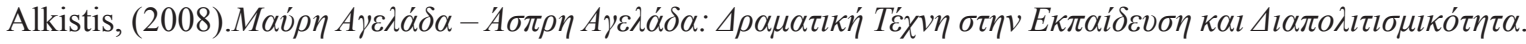

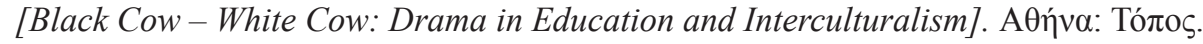

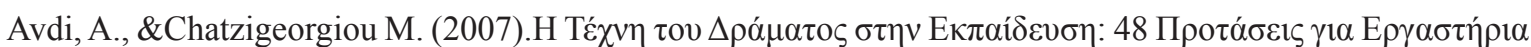

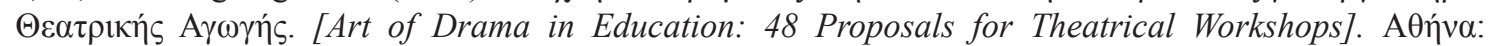

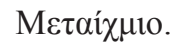

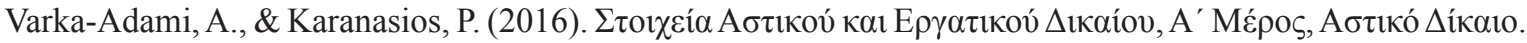

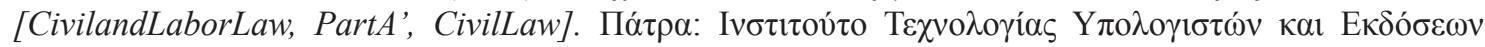

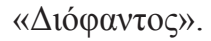

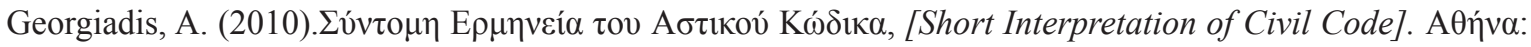

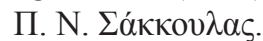

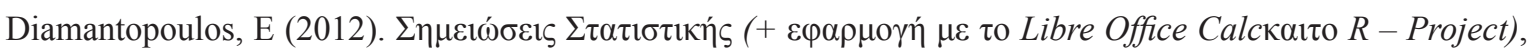

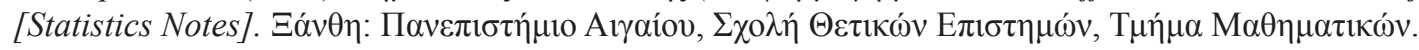

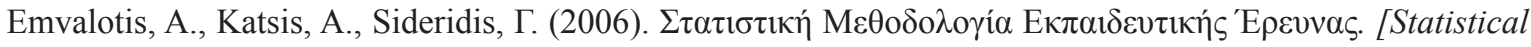

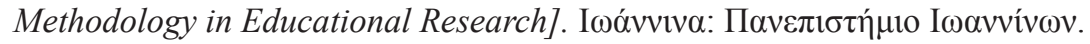

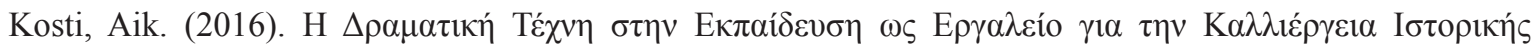

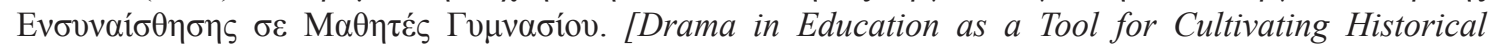

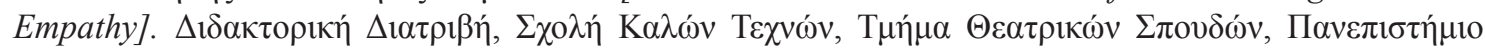

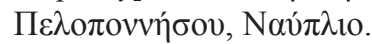

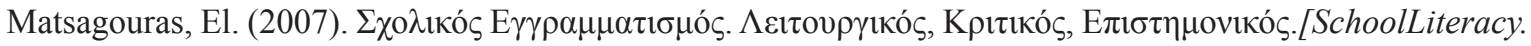

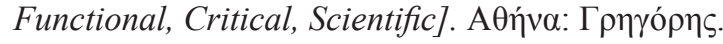

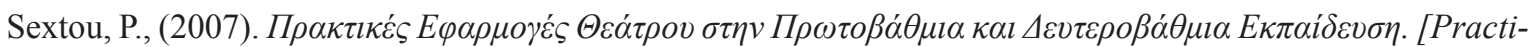

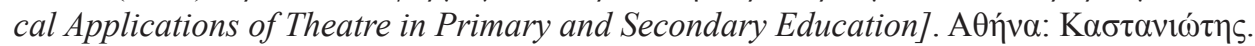

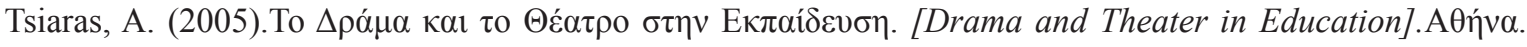

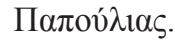


